\title{
Penerapan Model Algoritma Pemrograman Dalam Kehidupan Sehari-hari
}

\author{
Farhan Lubis \\ Fakultas Ilmu Tarbiyah Dan Keguruan \\ Program Studi Pendidikan Matematika \\ Universitas Islam Negeri Sumatera Utara \\ Kec . Delitua, Kabupaten Deli Serdang, Sumatera Utara \\ farhanlubis6990@gmail.com
}

\begin{abstract}
Abstrak
Kemajuan inovatif yang cepat saat ini membuatnya sangat mudah bagi kami untuk menangani berbagai masalah. Salah satu perangkat yang digunakan untuk menangani masalah tersebut adalah PC atau komputer. Bagaimana PC bisa menangani masalah kita? Karena tentunya PC tidak bisa bekerja secara alami tanpa ada yang menggerakkan dan mengisi PC tersebut. Cara penggunaan PC cenderung digunakan untuk menangani masalah dengan perhitungan dan bahasa pemrograman. Masalah itu bisa kita atasi dengan mengikuti langkahlangkah teratur membuat program yang berisi perhitungan di dalamnya. Perhitungan adalah premis rekayasa perangkat lunak yang berkonsentrasi pada metode yang paling mahir untuk mengatasi masalah dengan memiliki pilihan untuk mencari dan menggunakan dialek pemrograman. Setiap masalah yang diselesaikan menggunakan PC harus menggunakan perhitungan sebagai bahasa pemrograman. Alat-alat ini dapat dibuat dengan dokumentasi apa pun asalkan sederhana karena tidak ada dokumentasi standar yang direkam sebagai bahasa pemrograman hard copy. Setiap orang dapat membuat dan memuat bahasa pemrograman sendiri, namun agar bahasa pemrograman tersebut dapat diuraikan, ada baiknya jika bahasa pemrograman yang digunakan adalah melalui dokumentasi pemrograman secara keseluruhan. Standar untuk membuat perhitungan adalah memiliki judul, referensi kata, dan perhitungan yang sebenarnya. Ada 3 cara umum yang dikenal untuk menunjukkan dialek pemrograman, yaitu kalimat khusus yang jelas, diagram alur, dan penggunaan program Pascal (pseudocode).
\end{abstract}

Kata kunci: Algoritma, Flowchart, Bahasa Pascal, Penerapan Algoritma, Algoritma Pemprograman, dan Model Algoritma 


\section{PENDAHULUAN}

Algoritma sangat penting dalam menggunakan PC khususnya untuk menangani data. PC dibuat dari perhitungan yang menunjukkan arahan eksplisit oleh suatu program. Dalam aritmatika dan pemrosesan, algoritma adalah bermacam-macam perintah untuk mengatasi suatu masalah. Perintah ini dapat ditafsirkan sedikit demi sedikit dari awal sampai akhir. Isunya bisa apa saja, dengan catatan setiap terbitan ada standar kondisi awal yang harus dipenuhi sebelum menjalankan algoritma. Perhitungan akan secara konsisten berakhir untuk semua kondisi dasar yang memenuhi aturan, untuk situasi ini unik dalam kaitannya dengan heuristik. Algoritma secara teratur memiliki kemajuan berulang (kemahiran) atau memerlukan pilihan (alasan Boolean dan korelasi) sampai usaha selesai.

Kerumitan sebuah algoritma adalah proporsi dari seberapa banyak perhitungan algoritma yang dibutuhkan untuk mengatasi masalah tersebut. Biasanya, perhitungan yang dapat mengatasi masalah dalam jangka waktu yang singkat memiliki tingkat kerumitan yang rendah, sedangkan perhitungan yang menghabiskan sebagian besar hari untuk menangani suatu masalah memiliki tingkat kerumitan yang tinggi. Oleh karena itu, individu yang menggunakan PC harus melihat bagaimana fungsi algoritma. Ada banyak dialek pemrograman yang digunakan untuk menyusun algoritma numerik di PC. Bahasa pemrograman yang sering digunakan dicatat sebagai hard copy algoritma adalah bahasa pemrograman $\mathrm{C}$.

Salah satu ilustrasi algoritma pemrograman adalah diagram alur, kerangka diagram alur adalah diagram aliran yang menggambarkan pengaturan peralatan PC yang digunakan dalam penanganan informasi dan hubungan antara perangkat keras tersebut. Kerangka diagram alir tidak digunakan untuk menggambarkan susunan langkah-langkah untuk mengatasi suatu masalah, tetapi hanya untuk menggambarkan metodologi dalam kerangka yang dibentuk.

Algoritma adalah perkembangan pedoman PC untuk menyelesaikan tugas atau mengatasi masalah menggunakan cara yang sah. Seperti PC adalah otak kita. Secara konsisten dari saat kita bangun sampai kita istirahat lagi akan ada banyak latihan yang harus dilakukan. Memang, dalam menjalankannya, pikiran kita secara konsekuen akan mengatur langkahlangkah apa yang harus diikuti dengan tujuan agar pekerjaan itu selesai. Selanjutnya perhitungan tersebut dapat diterapkan dalam kehidupan sehari-hari biasa.

\section{METODE PENELITIAN}

Pada artikel ini penulis menggunakan suatu metode yaitu studi literatur, yang dimana studi literatur ini merupakan suatu metode dalam penelitian dengan menggunakan buku, jurnal, artikel, atau media masa lainnya yang digunakan sebagai bahan referensi untuk melakukan penelitian ini. Intisari yang ada didalam artikel ini berhubungan dengan Algoritma dan Pemprograman. Dimana materi ini merupakan suatu tuntunan tugas yang harus di selesaikan dengan tepat. Dalam artikel 
ini, ada banyak rundown perhitungan dan pemrograman, apa arti dan alasan bahan-bahan ini dan bagaimana menerapkan bahan-bahan ini. Dengan studi penulisan ini mahasiswa dapat memahami motivasi di balik mata kuliah perhitungan pemrograman ini, misalnya mahasiswa dapat memahami ide-ide dan perkembangan mendasar dalam perhitungan dan interpretasi atau interpretasi perhitungan ke dalam bahasa pemrograman. Dalam mata kuliah perhitungan pemrograman ini, mahasiswa juga harus dituntut untuk berpikir matang dalam menangani suatu masalah, misalnya masalah dalam berhitung yang harus dibuat mahasiswa dalam mata kuliah algoritma pemrograman ini.

\section{PEMBAHASAN}

Dalam penulisan ilmiah kata Algoritma berasal dari kata al-kwarizmi yang terdapat dalam kitab Abu Ja'far Muhammad Ibn Musa Al-Kwarizmi, seorang matematikawan dari Persia dengan judul bukunya "Polinomial matematika wal Muqabala". Dalam kitab-kitab tertentu terdapat beberapa pengertian perhitungan. Bagaimanapun, dengan asumsi bahwa kita melihat dengan hati-hati, buku-buku ini memiliki tujuan yang sama. Dalam buku ini, pengertian perhitungan adalah rencana langkah-langkah untuk mengatasi suatu masalah dengan sengaja dan runtut. Ada dua ekspresi kekhawatiran dalam definisi ini, khususnya metodis dan koheren.

Apalagi dengan pemrograman. Ide kerja dan dasar pemikiran pemrograman harus dilihat terlebih dahulu. Pemrograman tidak dapat dipisahkan dari ide fungsi sebuah PC, ada dasar pemikiran penting dari informasi, siklus dan hasil, menyiratkan bahwa ada informasi yang harus dimasukkan, baik secara langsung atau tidak langsung, yang kemudian akan, pada titik itu, ditangani, kemudian, pada titik itu, efek samping dari interaksi akan ditampilkan di layar atau di media hasil lainnya. .

Perhitungan adalah suatu pendirian yang harus dirasakan atau dikuasai oleh seseorang yang akan menangani suatu masalah dengan PC, untuk situasi ini dengan membuat sebuah program. Membangun sebuah program pada dasarnya adalah membuat suatu perangkat untuk mengatasi suatu masalah. Sebelum kita dapat membuat program yang dapat membantu kita dalam menangani masalah tersebut, kita dihadapkan pada 3 (tiga) tahapan mendasar, yaitu:

a) Memahami masalah dan alasan program dibuat pada tahap ini, kita harus memiliki opsi untuk membedakan jenis, struktur, dan kualitas informasi dan hasil normal. Namun, untuk masalah ruang lingkup yang sangat besar, terlepas dari jenis, bentuk dan kualitas, kita juga perlu mengetahui dengan pasti awal, pengulangan dan volume informasi dan tujuan normal, pengulangan dan volume informasi hasil.

b) Mampu mengumpulkan ide, rencana, rencana jawaban atas masalah yang akan kita bahas. Dari konsekuensi pemahaman kita tentang masalah di atas, kita harus memiliki opsi untuk merencanakan aliran siklus untuk menangani informasi input dan menghasilkan informasi hasil dengan jenis, bentuk, dan kualitas yang sesuai dengan bentuknya. 
c) Mampu melaksanakan konsekuensi dari rencana kita sebagai program yang terorganisir. Kita bisa membuat program dengan menggunakan bahasa pemrograman apapun. Konsekuensinya, kita dituntut untuk memahami dan menguasai bagian-bagian bahasa pemrograman dan metode pemrograman dengan baik.

Untuk tahap awal, mungkin secara eksklusif dengan sering berlatih memperhatikan dan memahami suatu masalah akan lebih dipertajam. Pada tahap selanjutnya, efek samping dari persepsi dan pemahaman terhadap isu-isu asli harus diisi dengan semacam aliran berpikir kritis. Hal ini sering disinggung sebagai algoritma. Ada pembenaran mengapa Anda harus merinci jawaban untuk masalah ini dalam aliran yang terorganisir. Hal ini dikarenakan PC sebagai perangkat mesin tidak dapat menangani masalah seperti orang yang sering berpikir tidak terstruktur. PC hanya dilengkapi untuk diminta secara berurutan dan meningkatkan kapasitas PC untuk melakukan perhitungan secara cepat dan massal.

Kemudian, pada tahap ketiga, efek samping dari pengaturan aliran berpikir kritis (yang telah dibingkai dalam desain algoritma) diterapkan ke PC melalui pembuatan program menggunakan bahasa pemrograman. Siklus ini biasanya disebut sebagai coding.

Suatu program pada hakikatnya mengandung suatu rangkaian pedoman yang saling berkaitan (membentuk suatu arus interaksi) dan diorganisasikan sehingga pada saat program dijalankan akan memberikan hasil yang normal. Dalam bahasa pemrograman apa pun, aliran panduan akan menjadi sesuatu yang sangat mirip untuk masalah serupa, perbedaannya hanya terletak pada metode penyusunan pedoman (tata bahasa) yang kontras dimulai dengan satu bahasa pemrograman kemudian ke yang berikutnya, seperti halnya dalam bahasa yang digunakan untuk menyampaikan antara orang-orang. Karena aliran dan jenis suatu perkembangan arah yang membahas dasar pemikiran dalam mengurus masalah, atau biasa disebut perhitungan. Disebut kalkulasi karena alur pemikirannya ditulis dalam struktur yang terorganisir sehingga tidak sulit untuk diimplementasikan ke dalam program melalui bahasa pemrograman apa pun.

Algoritma adalah rencana atau berbagai langkah yang dibuat dengan jelas dan terorganisir untuk memiliki pilihan untuk mengatasi suatu masalah. Rencana permainan sarana yang dimaksud adalah tindakan yang dibuat atau dikerjakan dari bahasa pemrograman yang dapat dibedakan dan dirasakan oleh PC. Langkah-langkah tindakan yang dibuat dalam perhitungan ini dibuat untuk memiliki opsi untuk mengatasi pemikiran kritis secara lebih memadai dan efektif dengan waktu yang digunakan untuk menangani masalah, hanya membutuhkan waktu lebih sedikit (cepat). Ada beberapa contoh penggunaan perhitungan dalam kehidupan sehari-hari biasa. Seperti saat kita hendak membuat espresso, ada langkahlangkah yang perlu kita lakukan dalam membuat espresso, caranya adalah: ambil kuali dan isi dengan air bersih, kemudian panaskan di atas kompor dan tunggu sampai air tersebut mendidih. Siapkan gelas atau cangkir kemudian, isi dengan gula pasir dan bubuk espresso secukupnya, kemudian tuangkan air yang sangat panas ke dalam gelas atau cangkir yang 
sudah berisi gula dan bubuk espresso, kemudian, aduk hingga gula larut dan merata, barulah espresso bisa dinikmati. Berikut adalah sedikit gambaran tentang pemanfaatan perhitungan dalam kehidupan sehari-hari biasa, mengingat perhitungan dapat dianggap sebagai tahap dalam menyelesaikan teknik dalam melakukan tugas yang sering dilakukan dalam latihan sehari-hari. Jadi perhitungannya adalah langkah yang efisien, masuk akal, dan lengkap untuk mengatasi suatu masalah.

Ada dua cara menyusun algoritma, yaitu:

1) Menggunakan bagan-bagan/simbol-simbol tertentu yang membentuk bagan alir (flowchart).

2) Menggunakan kata-kata atau kalimat maternatis.

Simbol-simbol yang umum dipakai untuk menyusun algoritma menggunakan flowchart adalah simbol-simbol berikut:

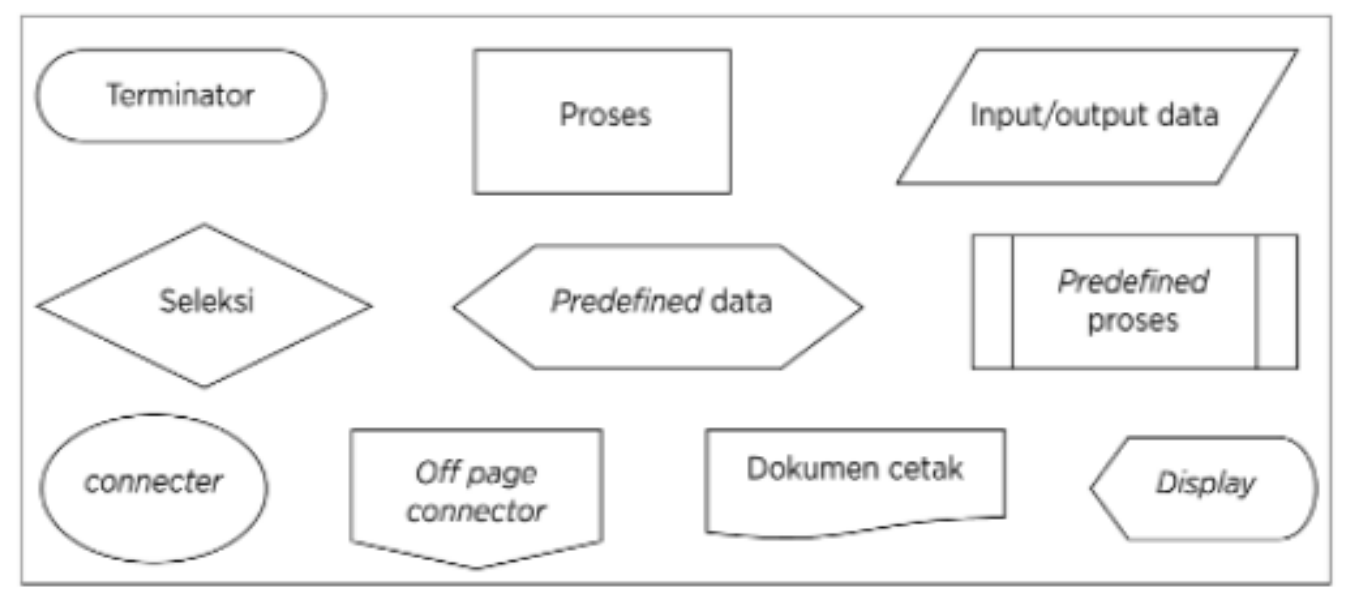

Terdapat karakteristik tersendiri dari Algoritma yang membedakannya dengan suatu penyelesaian masalah yang mengunakan metode yang berbeda. Berikut adalah ciri-ciri algoritma:

- Algoritma memiliki awalan dan akhiran.

- Setelah mengerjakan langkah tertentu, algoritma harus berhenti.

- Setiap langkah harus didefinisikan dengan jelas dan tepat sehingga tidak multi-tafsir atau bermakna dua (am bigu).

- Algoritma harus memiliki masukan minimal satu.

- Algoritma memiliki keluaran minimal satu.

- Algoritma harus efektif. Maksudnya didalam semua langkah yang ditulis harus simple, sehingga akan dapat dikerjakan dalam waktu yang singkat serta masuk. 
Setelah memahami pentingnya dan sifat-sifat perhitungan, maka selanjutnya harus memahami seluk-beluk perhitungan tersebut. Sebuah perhitungan dianggap sangat bergantung pada E. Knuth dengan asumsi perhitungan memenuhi kondisi berikut:

- Finiteness

Algoritma harus benar-benar selesai ketika algoritma telah menjalankan beberapa langkah interaksi.

- Definiteness

Setiap perkembangan dalam algoritma harus dicirikan secara definitif. Cobalah untuk tidak menggunakan pedoman yang tidak jelas atau tidak pasti.

- Input

Algoritma mengharapkan informasi untuk ditangani sebagai info atau informasi. Hasil

Sebuah algoritma yang dibuat atau digabungkan akan memberikan suatu tempat di sekitar satu hasil.

- Effectiveness

Setiap perkembangan yang digunakan dalam algoritma harus masuk akal dan harus dilakukan secara memadai.

Sedangkan secara garis besar, penyajian algoritma terdapat tiga bentuk yakni kalimat deskriptif, pseudocode dan flowchart.

- Kalimat Deskriptif

Penyampaian algoritma dengan cara kalimat adalah yang paling sering dijumpai dalam kehidupan sehari-hari. Semisal, langkah-langkah memasak mie instan, menyeduh kopi, mandi dan lain-lain. Seperti namanya, cara penyajian ini menggunakan kalimat dengan mendeskripsikan langkah demi langkah untuk menyelesaikan suatu masalah.

\section{Contoh : Menyeduh Kopi Toraja}

1) Siapkan 1 buah gelas yang kosong dan bersih

2) Ambil kopi satu sendok makan lalu masukkan ked alam gelas

3) Tambahkan gula secukupnya

4) Panaskan air hingga mendidih

5) Tuangkan air mendidih kedalam gelas

6) Aduk kurang lebih 1 menit

7) Setelah diaduk, kopi siap dihidangkan

- Pseudocode

Pseudocode merupakan penyajian algoritma yang mirip dengan sintaks bahasa pemrograman yaitu mirip dengan bahasa Pascal dan juga bahasa C. Jadi dokumentasi ini sangat cocok digunakan untuk menggambarkan perhitungan yang akan melibatkan pengembang. Penulisan pseudocode terdiri dari 3 bagian, khususnya: 
Area judul, segmen Judul dimulai dengan "Algoritma" dan diikuti dengan nama algoritma. Umumnya nama algoritma hanya terdiri dari 1 kata. Jika lebih dari satu kata, judul akan dituliskan menjadi kata (disambung) atau dengan menggunakan simbol

underscore ( $\_$). Contoh :

\section{ALGORITMA LAMABEKERJA}

(algoritma untuk menghitung lama bekerja seorang karyawan)

\section{Atau:}

\section{ALGORITMA LAMA_BEKERJA}

\section{falgoritma untuk menghitung lama bekerja seorang karyawan)}

Area deklarasi, Deklarasi digunakan untuk mendeklarasikan variabel yang akan digunakan didalam algoritma dan juga tipe data-nya. Bagian deklarasi biasaya ditulis dengan kata "KAMUS DATA". Format penulisan bagian adalah dengan menulis nama variabel lalu diikuti dengan tipe data. Contoh :

\section{KAMUS DATA}

jMasuk, jKeluar, LBekerja: integer

Area isi, Bagian ini merupakan bagian utama dari suatu algoritma. Berisi instruksi sesuai dengan logika pada algoritma. Instruksi-instruksinya dapat berupa perintah yang bersifat runtutan, pemilihan, perulangan, atau bahkan kombinasi dari ketiganya. Penulisan bagian isi biasanya diawali dengan kata "BEGIN" dan diakhiri dengan kata "END". Format penulisan dari bagian isi adalah sebagai berikut:

\section{BEGIN \\ Input jMasuk \\ Input jKeluar \\ END}

Untuk menggambarkan suatu algoritma secara utuh mulai dari Judul, Deklarasi, dan Isi perhatikan contoh berikut: 


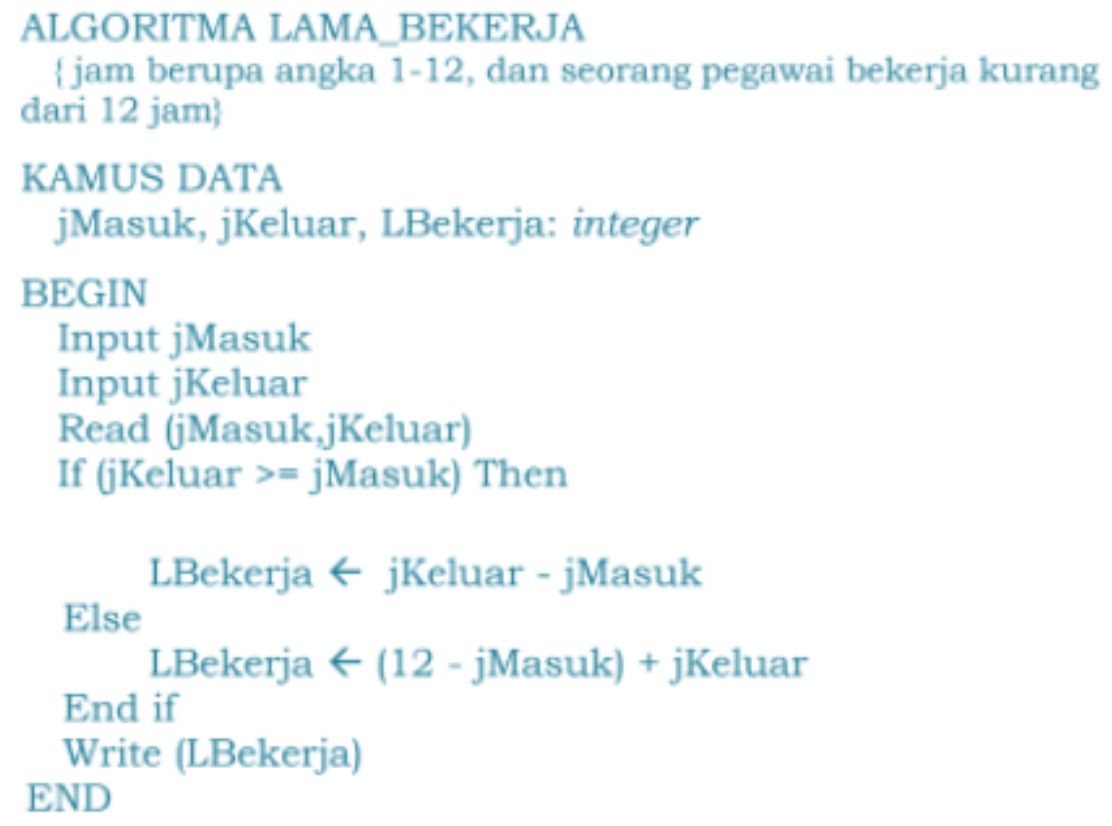

- Flowchart

Flowchart atau diagram alir merupakan penyajian algoritma dengan cara menggambarkan aliran instruksi secara visual. Notasi algoritma ini hanya cocok untuk menyelesaikan persoalan yang lingkupnya kecil, tidak cocok untuk persoalan yang lingkupnya besar karena akan memerlukan tempat yang luas untuk menggambarkan aliran instruksi.

Contoh dari flowchart :

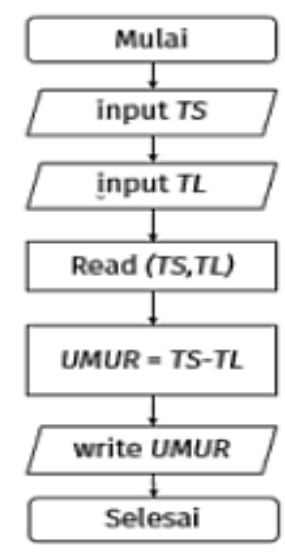

Perlu dipahami bahwa penulisan algoritrna sangat universal, atau dengan kata lain tidak mengikat. Yang terpenting adalah orang yang membacanya dapat mengerti maksud yang ingin dicapai.

A. Penerapan Model Algoritma Pemprograman Dalam Kehidupan Sehari-hari 
1. Permohonan Verifikasi Kepulangan Warga Pemasyarakatan Menggunakan Algoritma Knuth Morris Pratt (Woro Isti Rahayu dan Ajis Trigunawan, 2021)

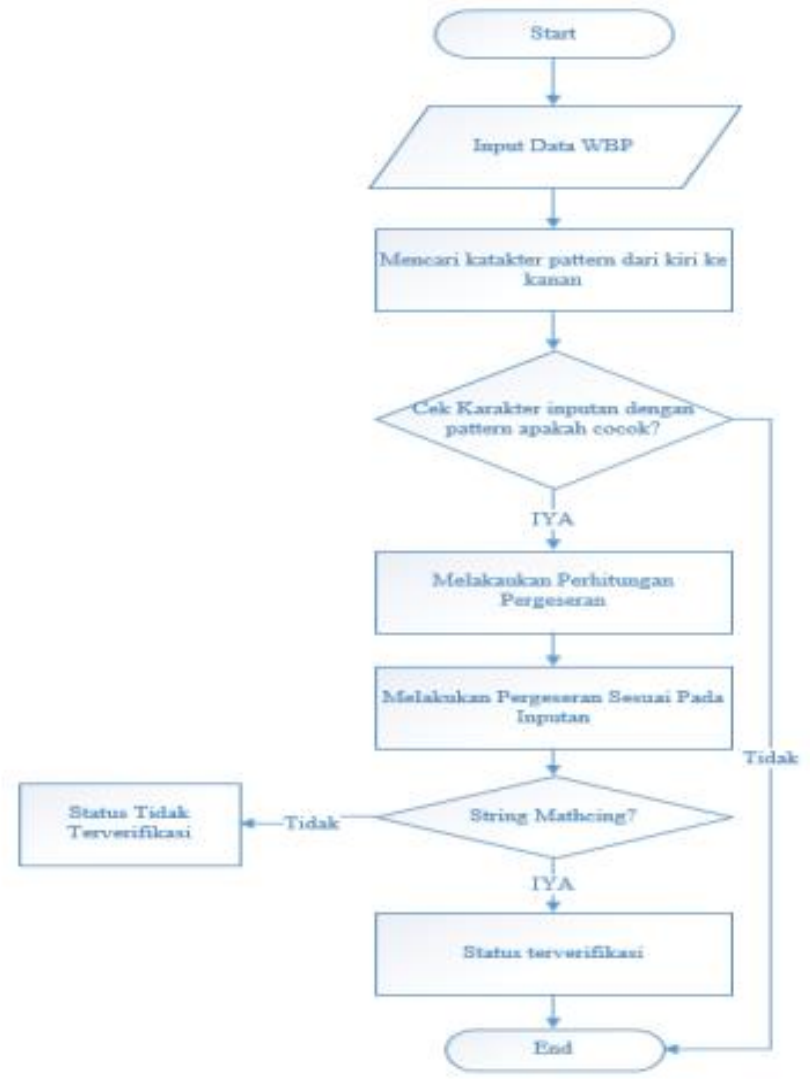

Cara kerja:

Seperti yang ditunjukkan oleh (Woro Isti Rahayu dan Ajis Trigunawan, 2021) pelaksanaan siklus pencocokan string sambil menegaskan kepemilikan melalui pencocokan balasan atau jawaban di mana petugas narapidana akan menegaskan kedatangan narapidana dengan mencocokkan tanggapan terhadap beberapa pertanyaan sehubungan dengan karakter tahanan, dan perhitungan knuth morris pratt. akan memainkan cara yang paling umum untuk mencocokkan tanggapan yang sesuai, memanfaatkan algoritma knuth morris pratt dalam melakukan koordinasi teks.

String : RISALAH

Pattern : SALAH

Tahapan pencarian pattern (P) dalam Teks (S) :

- Pada pergeseran Ke-1 Pattern tidak cocok dengan string. Maka pattern akan bergeser satu posisi ke kanan. 


\begin{tabular}{|l|l|l|l|l|l|l|l|}
\hline String & R & I & s & a & l & a & h \\
\hline Pattern & S & a & l & a & h & & \\
\hline
\end{tabular}

- Pada pergeseran Ke-2 Pattern tidak cocok dengan string. Maka pattern akan bergeser satu posisi ke kanan.

\begin{tabular}{|l|l|l|l|l|l|l|l|}
\hline String & $\mathrm{R}$ & $\mathrm{i}$ & $\mathrm{s}$ & $\mathrm{a}$ & $\mathrm{l}$ & $\mathrm{a}$ & $\mathrm{h}$ \\
\hline Pattern & & $\mathrm{S}$ & $\mathrm{a}$ & $\mathrm{l}$ & $\mathrm{a}$ & $\mathrm{h}$ & \\
\hline
\end{tabular}

- Pada pergeseran Ke-3 Pattern tidak cocok dengan string. Maka pattern akan bergeser satu posisi ke kanan.

\begin{tabular}{|l|l|l|l|l|l|l|l|}
\hline String & R & I & S & a & 1 & a & h \\
\hline Pattern & & & S & a & 1 & a & h \\
\hline
\end{tabular}

- Pada pergeseran ke-4, pattern cocok dengan string. Karena ada kecocokan, perhitungan desain Knuth Morris Prat tidak akan bergerak dan tetap mengoordinasikan contoh dengan string.

\begin{tabular}{|l|l|l|l|l|l|l|l|}
\hline String & R & I & s & a & 1 & $\mathrm{a}$ & $\mathrm{h}$ \\
\hline Pattern & & & S & a & 1 & $\mathrm{a}$ & $\mathrm{h}$ \\
\hline
\end{tabular}

- Pada shift ke-5, pattern cocok dengan string. Karena ada kecocokan, perhitungan desain Knuth Morris Prat tidak akan bergerak dan tetap mengoordinasikan contoh dengan string

\begin{tabular}{|l|l|l|l|l|l|l|l|}
\hline String & R & I & S & a & 1 & $\mathrm{a}$ & $\mathrm{h}$ \\
\hline Pattern & & & S & a & 1 & $\mathrm{a}$ & $\mathrm{h}$ \\
\hline
\end{tabular}

- Pada pergeseran ke-6, pattern cocok dengan string. Karena ada kecocokan, perhitungan desain Knuth Morris Prat tidak akan bergerak dan tetap mengoordinasikan contoh dengan string.

\begin{tabular}{|l|l|l|l|l|l|l|l|}
\hline String & R & I & S & a & l & a & h \\
\hline Pattern & & & S & a & 1 & $\mathrm{a}$ & $\mathrm{h}$ \\
\hline
\end{tabular}

- Pada pergeseran ke-7, pattern cocok dengan string. Karena ada kecocokan, perhitungan desain Knuth Morris Prat tidak akan bergerak dan tetap mengoordinasikan contoh dengan string. Namun, karena jumlah contoh hanya 6 huruf, pertanyaan akan dihentikan dan hasilnya adalah desain P cocok dengan string S sebesar 100 persen.

\begin{tabular}{|l|l|l|l|l|l|l|l|}
\hline String & $\mathrm{R}$ & $\mathrm{I}$ & $\mathrm{s}$ & $\mathrm{a}$ & $\mathrm{l}$ & $\mathrm{a}$ & $\mathrm{h}$ \\
\hline Pattern & & & $\mathrm{S}$ & $\mathrm{a}$ & $\mathrm{l}$ & $\mathrm{a}$ & $\mathrm{h}$ \\
\hline
\end{tabular}


Dengan adanya aplikasi konfirmasi kedatangan tahanan dengan menggunakan perhitungan Knuth Morris Pratt akan membantu kecepatan dalam meningkatkan proses pemeriksaan kembali bagi narapidana, dimana interaksi ini dibantu dengan perhitungan pada jam pencocokan string untuk konfirmasi pembebasan.

2. Pemanfaatan Algoritma Knuth-Morris-Pratt Pada Fungsi Pencarian Dokumen Sistem Informasi Administrasi Sekolah Berbasis Website (Imam Maulana dan Normalisa, 2019)

Dalam International Journal of Artificial Intelligence yang disusun oleh (Imam Maulana dan Normalisa, 2019) menyatakan dalam pembuatannya melalui beberapa peroses diantaranya yaitu:

a) Analisa Algoritma Knuth-Morris-Pratt

Algoritma yang digunakan untuk pencocokan string dalam daya tampung Sistem Informasi Administrasi Sekolah menggunakan perhitungan Knuth-Morris-Pratt (KMP). Perhitungan KMP merupakan perhitungan yang dikembangkan secara mandiri oleh D. E. Knuth pada tahun 1967, dan J.H. Morris dengan V.R. Pratt pada tahun 1966, namun seluruhnya didistribusikan pada waktu yang sama pada tahun 1977.

Psudocode alogaritma KMP.

\begin{tabular}{|c|c|}
\hline Psudocode alogaritma KMP. & Fase Pencarian \\
\hline $\begin{array}{l}\text { Procedure preKMP ( } \\
\text { input } P \text { : array[0...n-1] of char, } \\
\text { input } n: \text { integer, input/output kmpNext : } \\
\text { array[0...n] of integer } \\
\text { ) } \\
\text { Deklarasi : } \\
\text { i,j : integer } \\
\text { Algoritma } \mathrm{i}:=0 \text {; } \\
\mathrm{j}:=\mathrm{kmpNext}(0):=-1 ; \\
\text { while }(\mathrm{i}<\mathrm{n})\{ \\
\text { while }(\mathrm{j}>-1 \text { and not } \\
(\mathrm{P}[\mathrm{i}]= \\
\mathrm{P}[\mathrm{j}])) \\
\mathrm{j}:=\mathrm{kmpNext}[\mathrm{j}] ; \mathrm{i}:=\mathrm{i}+1 ; \\
\mathrm{j}:=\mathrm{j}+1 ; \\
\text { if }(\mathrm{p}[\mathrm{i}]=\mathrm{P}[\mathrm{j}]) \mathrm{kmpNext}[\mathrm{i}]:= \\
\mathrm{kmpNext}[\mathrm{j}] ; \\
\text { else } \\
\mathrm{kmpNext}[\mathrm{i}]:=\mathrm{j} \text {; endif } \\
\text { endwhile }\end{array}$ & 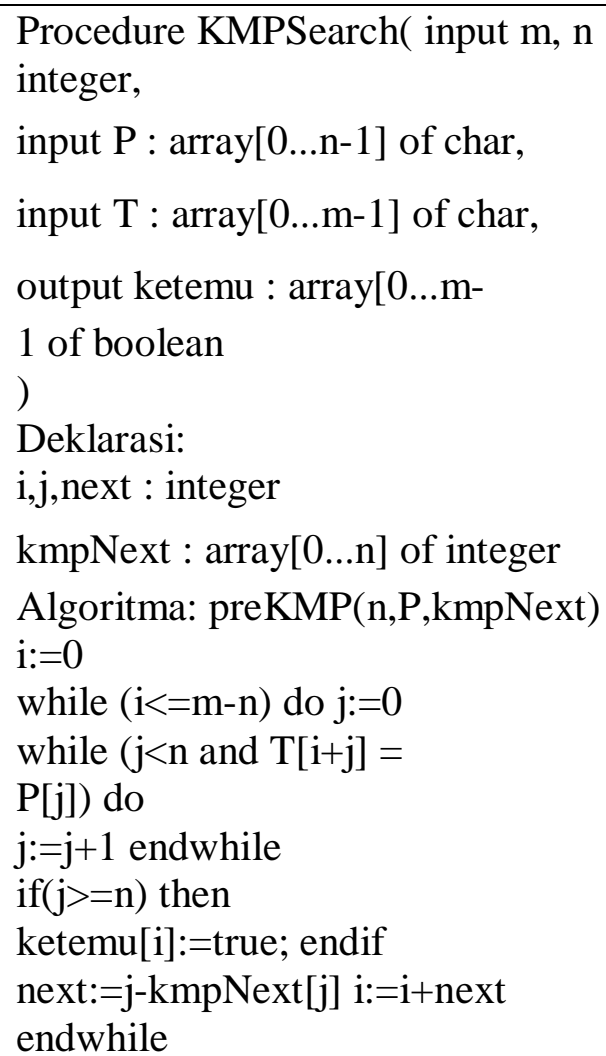 \\
\hline
\end{tabular}


Dilihat dari pseudocode, cenderung terlihat bahwa cara yang dilakukan oleh perhitungan Knuth-Morris-Pratt saat mencocokkan string adalah sebagai berikut:

Perhitungan Knuth-Morris-Pratt mulai mencocokkan contoh di awal teks.

1. Dari kiri ke kanan, algoritma ini akan mengoordinasikan orang menurut karakter contoh dengan orang dalam teks terkait, sampai salah satu kondisi yang menyertainya terpenuhi, Karakter dalam contoh dan teks yang dilihat tidak koordinat (bingung) dan setiap karakter dalam contoh cocok. Kemudian, pada saat itu, algoritma akan memberi tahu pengungkapan pada posisi ini.

2. Algoritma kemudian memindahkan pattern tergantung pada tabel berikut, kemudian pada titik itu, mengulangi cara-cara tersebut sampai contoh tersebut menuju akhir teks. Pemanfaatan algoritma Knuth-Morris-Pratt untuk pekerjaan scan laporan untuk Sistem Informasi Administrasi Sekolah digambarkan dalam kemajuan berikut:

String S:

\begin{tabular}{|c|c|c|c|c|c|c|c|c|}
\hline $\mathrm{S}$ & $\mathrm{o}$ & $\mathrm{p}$ & $\mathrm{t}$ & $\mathrm{e}$ & $\mathrm{k}$ & $\mathrm{n}$ & $\mathrm{i}$ & $\mathrm{s}$ \\
\hline
\end{tabular}

Pattern P:

\begin{tabular}{|l|l|l|l|l|l|}
\hline $\mathrm{T}$ & $\mathrm{e}$ & $\mathrm{k}$ & $\mathrm{n}$ & $\mathrm{i}$ & $\mathrm{s}$ \\
\hline
\end{tabular}

- Langkah 1, bandingkan P(1) dengan S(1)

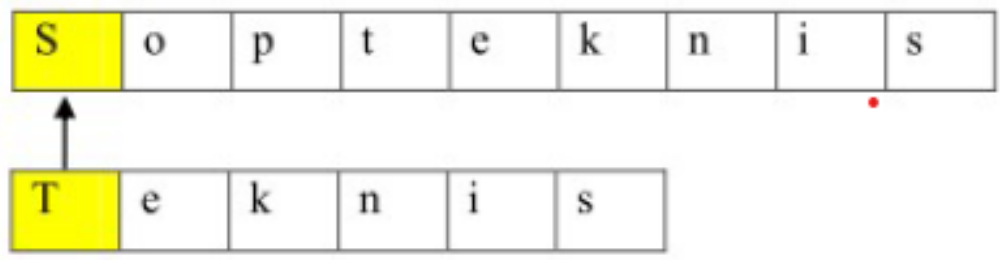

- $\quad \mathrm{P}(1)$ tidak cocok dengan $\mathrm{S}(1)$, maka pada saat itu, pattern akan memindahkan satu situasi ke satu sisi yaitu ke sisi kanan. Tahap 2, pikirkan $\mathrm{P}(1)$ dengan $\mathrm{S}(2)$.

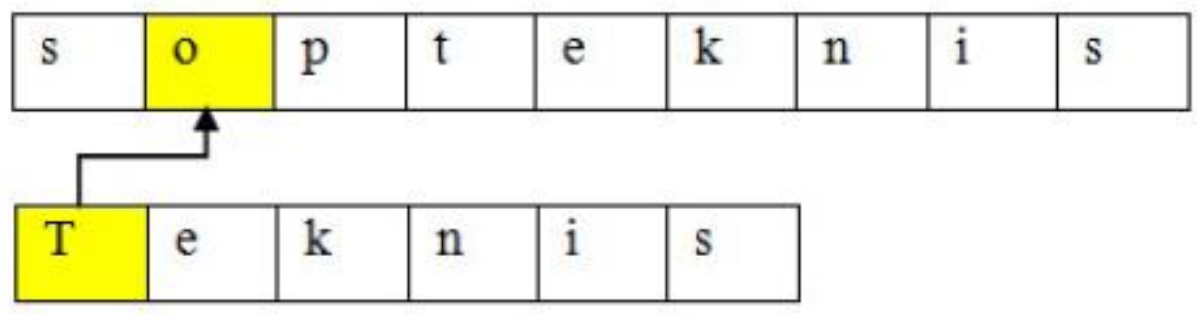


- $\mathrm{P}(1)$ tidak cocok dengan $\mathrm{S}(2)$, maka pada saat itu, pattern akan memindahkan satu situasi ke satu sisi yaitu kesisi kanan. Tahap 3, pikirkan $\mathrm{P}(1)$ dengan $\mathrm{S}(3)$

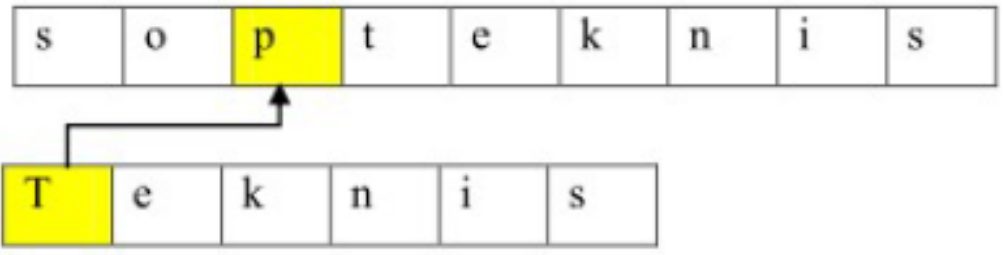

- $\quad \mathrm{P}(1)$ tidak cocok dengan $\mathrm{S}(3)$, maka pada saat itu, pattern akan memindahkan satu situasi ke satu sisi yaitu kesisi kanan. Tahap 4, analisis $\mathrm{P}(1)$ dengan $\mathrm{S}(4)$

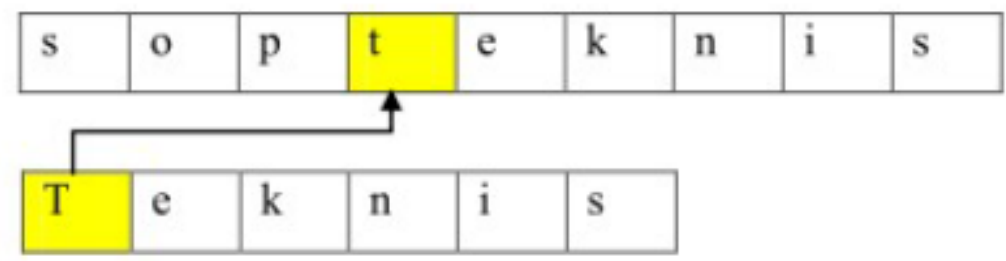

- $\mathrm{P}(1)$ cocok dengan S(4), kemudian pada saat itu, algoritma Knuth-Morris-Pratt akan menyimpan data ini, dan pattern tidak akan bergerak dan terus mencocokkan $\mathrm{P}(2)$ dengan $\mathrm{S}$ (5). Tahap 5, lihat $\mathrm{P}(2)$ dengan $\mathrm{S}(5)$

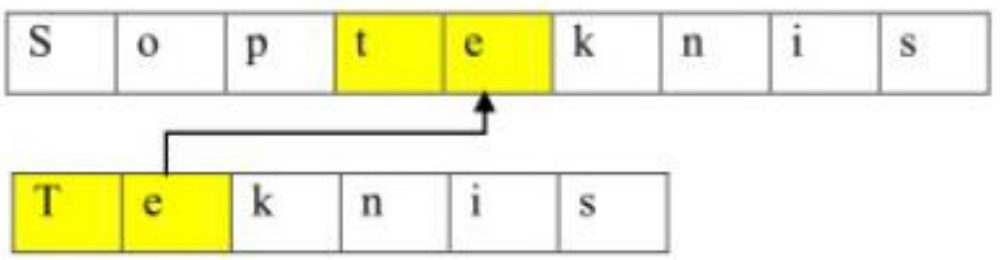

- $\mathrm{P}(2)$ cocok dengan $\mathrm{S}(5)$, kemudian pada saat itu, algoritma Knuth-Morris-Pratt akan menyimpan data ini, dan contoh tidak akan bergerak dan tetap mencocokkan $\mathrm{P}(3)$ dengan $\mathrm{S}(6)$. Tahap 6, analisis $\mathrm{P}(3)$ dengan $\mathrm{S}(6)$

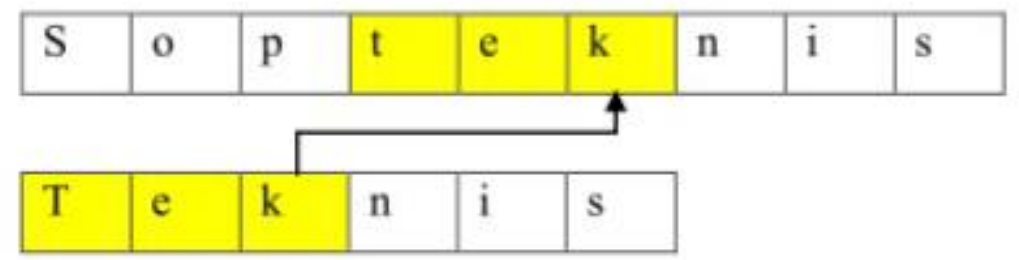

- $\mathrm{P}(3)$ cocok dengan $\mathrm{S}(6)$ kemudian pada saat itu, algoritma Knuth-Morris-Pratt akan menyimpan data ini, dan pattern tidak akan bergerak dan tetap mencocokkan $\mathrm{P}(4)$ dengan S(7). Tahap 7, lihat $\mathrm{P}(4)$ dengan $\mathrm{S}(7)$ 


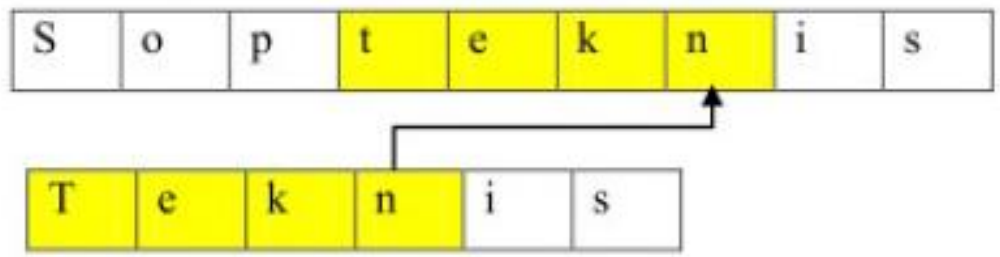

- $\mathrm{P}(4)$ cocok dengan S(7) kemudian pada saat itu, algoritma Knuth-Morris-Pratt akan menyimpan data ini, dan pattern tidak akan bergerak dan terus mencocokkan $\mathrm{P}(5)$ dengan $\mathrm{S}(8)$ Langkah 8, lihat $\mathrm{P}(5)$ dengan $\mathrm{S}(8)$.

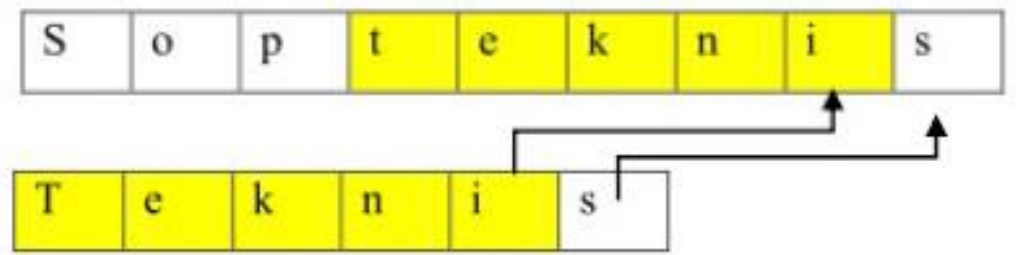

- $\mathrm{P}(5)$ cocok dengan $\mathrm{S}(8)$ kemudian pada saat itu, algoritma Knuth-Morris-Pratt akan menyimpan data ini, dan pattern tidak akan bergerak dan terus mencocokkan $\mathrm{P}(9)$ dengan $\mathrm{S}(8)$. Tahap 9, lihat $\mathrm{P}(6)$ dengan $\mathrm{S}(9)$

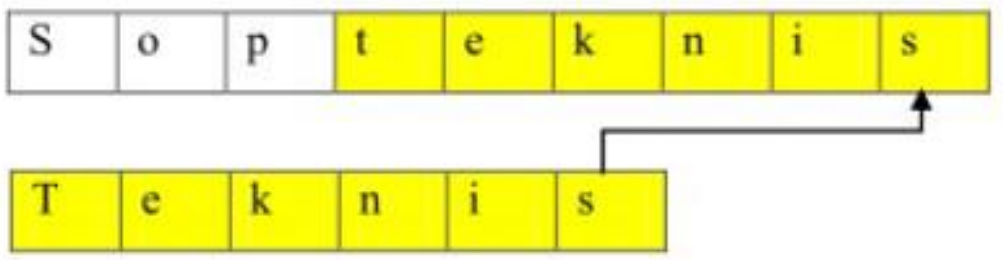

$\mathrm{P}(6)$ cocok dengan $\mathrm{S}(9)$, kemudian pada saat itu, algoritma Knuth-Morris-Pratt akan menyimpan data ini, dan pattern tidak akan bergerak dan terus mencocokkan $\mathrm{P}(7)$ dengan S(10). Namun, karena jumlah pattern hanya 6 huruf, pertanyaan akan dihentikan dan hasilnya adalah desain $\mathrm{P}$ cocok dengan string $\mathrm{S}$ sebesar $100 \%$. Jika setiap huruf dalam pattern telah dicocokkan dengan string, pattern jargon akan ditemukan dalam string. Dalam melacak pattern dalam string itu, akan bergerak beberapa kali untuk mencocokkan setiap huruf dalam pattern mulai dari kiri untuk mencocokkan setiap huruf dalam string. Diagram alir Algoritma Knuth-Morris-Pratt diperkenalkan pada gambar terlampir. 


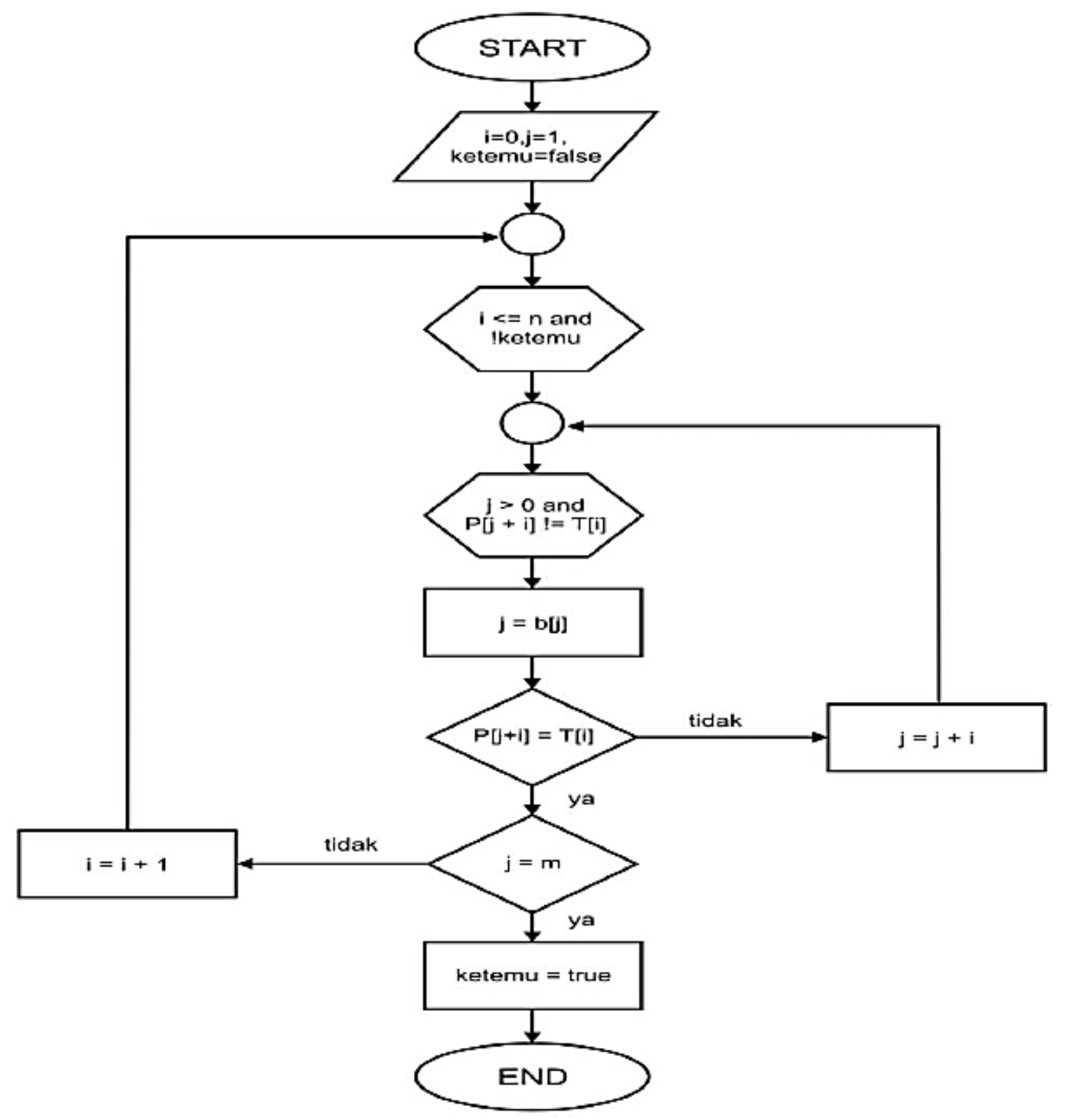

Gambar Flowchart Algoritma Knuth-Morris-Pratt

\section{Kesimpulan}

Dalam pembahasan dikemukakan bahwa kata "Algoritma" berasal dari kata al-kwarizmi yang terdapat di buku Abu Ja'far Muhammad Ibnu Musa Al-Kwarizmi, seorang ahli Matematika dari Persia dengan judul bukunya "Aljabar wal Muqabala". Algoritma adalah rencana permainan langkah-langkah untuk mengurus suatu masalah dengan sengaja dan runtut. Secara keseluruhan, tampilan algortima memiliki tiga struktur, yaitu kalimat yang menarik, pseudocode dan flowchart. Banyak kelebihan atau kegunaan algoritma dalam kehidupan sehari-hari yang sering digunakan misalnya, "Permohonan Verifikasi Kepulangan Narapidana Menggunakan Algoritma Knuth Morris Pratt" dalam (Woro Isti Rahayu dan Ajis Trigunawan, 2021). Dalam pembuatan 
aplikasi ini, perhitungan pemrograman yang sangat berharga digunakan untuk membantu mengkonfirmasi kedatangan tahanan ke kantor perbaikan. Model lainnya adalah " Pemanfaatan Algoritma Knuth-Morris-Pratt Pada Fungsi Pencarian Dokumen Sistem Informasi Administrasi Sekolah Berbasis Website (Imam Maulana dan Normalisa, 2019)“. Masih banyak lagi penerapan-penerapan model algoritma pemprograman lainnya, tetapi pada kesempatan kali ini saya hanya memaparkan dua diantaranya.

Daftar Rujukan

D. A. Prapto, and M. Purwaningsih, "Pengembangan Aplikasi Dokumen Manajemen untuk Departemen Pemerintahan," Seminar Nasional Informatika 2008 (semnasIF 2008), pp. 82-87, 2008

H. T. Sa'diah, "Implementasi Algoritma Knuth-Morris-Pratt pada Fungsi Pencarian Judul Tugas Akhir Repository”, Jurnal Komputasi, vol. 14, no. 1, pp. 1-9, 2017.

J. I. E. B. M. a. E. B. Sinaga, "Aplikasi Mobile Pencarian Kata Pada Arti Ayat Al-Qur'an Berbasis Android Menggunakan Algoritma String Matching," Vol. 2 No. 2 Juni 2016, 2016.

K. W. Argakusumah and S. Hansun, "Implementasi Algoritma Boyer-Moore pada Aplikasi Kamus Kedokteran Berbasis Android," 2014.

Maulana, Imam dan Normalisa, “Algoritma Knuth-Morris-Pratt pada Fungsi Pencarian Dokumen untuk Sistem Informasi Administrasi Sekolah Berbasis Website". International Journal of Artificial Intelligence, vol 6, 2019.

M. Rossaria, B. Susilo, and Ernawati, "Implementasi Algoritma Pencocokan String Knuth_Morris-Pratt dalam Aplikasi Pencarian Dokumen Digital Berbasis Android", Jurnal Rekursif, vol. 3, no. 2, pp. 183-195, 2015.

Rahayu, Woro Isti dan Ajis Trigunawan, "Aplikasi Verifikasi Kepulangan Warga Binaan Pemasyarakatan Menggunakan Algoritma Knuth Morris Pratt". Jurnal Teknik Informatika, Vol. 13, No. 1, 2021.

Rerung, Rintho Rante.2020. “Algoritma Dan Struktur Data Untuk Perguruan Tinggi”. Sumatera Barat : INSAN CENDEKIA MANDIRI.

S. S. Shenoy, . U. S. Nayak and B. Neelima, "SWIFT-A Performance Accelerated Optimized String Matching Algorithm for Nvidia GPUs," 2017.

Sahyar, 2016."Algoritma \& Pemprograman Menggunakan Matlab (Matrix Laboratory)".Jakarta: KENCANA.

Sitorus, Lamhot. (D. A. Prapto, 2008)2015. “Algoritma Dan Pemprograman”.Yogyakarta : ANDI, anggota IKAP. 
Tukino, "Perancangan Sistem Informasi Manajemen Proyek Pengaksessan Dokumen Perakitan PCBA," di PT Surya Teknologi Batam Berbasis Web, TEKNOSI (Jurnal Teknologi dan Sistem Informasi), vol. 2, no. 3, pp. 67-84, 2016. 